\title{
LÍNEA DE CUMBRES
}

Dionisia GARCÍA

Fulgencio Martínez (Murcia, 1960) es «poeta profesor», por decirlo con palabras de Jorge Guillén. En el recuerdo quedan sus libros: León busca gacela, Prueba de sabor, El cuerpo del día, Cancionero de rimas burlescas y El año de la lentitud, por citar algunos otros. También cuenta con libros de diferentes géneros: relatos, ensayo, artículos de opinión y escritura literaria. Destaquemos el ensayo sobre la filosofía de Antonio Machado. No hemos de olvidar que nuestro autor fundó la revista literaria Ágora, de gran repercusión.

Hoy, nuestro comentario se centra en Linea de cumbres $^{1}$. La singularidad de sus páginas es latente, y ello por estar escritas en periodos diferentes de la vida (así lo anota el poeta), donde la sensibilidad y los escenarios son distintos. Sin duda, estas características enriquecen lo escrito.

El libro se inicia con el poema «Aprendiendo las reglas de la casa». Digamos que es un tratado donde, a través de sus versos, se dice del poeta y el poema, de las dificultades del arte (el poema que se «precie» las conoce). Unos versos pueden resumir y aclarar la intención del poema: «La suma predecible o el azar / de su resultado incierto, eres tú / la conciencia de este instante / que huye y que tratas de apresar / con la palabra...». El poeta va del pasado al presente, sin dejar de transitar los espacios intermedios, donde va desgranando vida, razones y visión del mundo, además de las desquerencias de sí mismo («Toda mi vida ha sido un accidente / un jugar de prestado una jugada...»). Otros temas son altamente tratados: el amor, la amistad, la inocencia en los poemas adolescentes, la naturaleza (tocada con bellos versos: «el rumor de la tarde en los naranjos»). No hay nada banal en este libro. Las palabras, los versos, surgen de lo hondo como resultado de la reflexión, sin que tema alguno quede fuera de su mirada. Así ocurre con el poema «Noticia»; en él escribe de «...la era de la simplificación», tan de actualidad.

Alegría también encontramos en esta Línea de cumbres al descubrir «tanto amor a la vida» y «el rostro de mi corazón», que indudablemente es un hallazgo, y de un intenso lirismo.

\footnotetext{
${ }^{1}$ Fulgencio Martínez, Linea de cumbres, Madrid, Adarvo, 2020, 111 págs.
} 
La luz llega en sus distintos momentos, para contrarrestar las sombras, interiores y externas, porque la vida fluye en estos versos, tanto si el imaginario poético lo encontramos en segunda persona, bastante frecuente, o en un yo interiorizado que surge en algunos poemas, sobre todo en la última parte del libro: «Humor o fe», «Poemas fuera de agenda», anota el autor. Son poemas escritos en aquellos años, casi niños, precedidos por los de su última escritura (2019).

Finalicemos diciendo que Línea de cumbres es un libro en «movimiento». De él podríamos añadir otros aspectos, pero será preferible dejar al lector que descubra en muchos de sus versos el camino andado por el poeta para dejar, en nuestras manos, un libro luminoso. 